\title{
The Effect of Leadership, Reward And Punishment on Employee Performance (Case Study Sambel Layah Corporation Purwokerto)
}

\author{
Fatmah Bagis, Bima Cinintya Pratama \\ \{fatmahbagis2014@gmail.com\} \\ Fakultas Ekonomi dan Bisnis, Universitas Muhammadiyah Purwokerto
}

\begin{abstract}
This study explain about the effect of leadership, reward, and punishment on employee performance. The method used in this study is case study on Sambel Layah Corp Purwokerto. Questionare were administered to 123 employees of Sambel Layah Corp Purwokerto using purposive sampling techniques. Data analysis technique used are the multiple regression analysis. The results showed that the variables of leadership, reward and punishment simultaneously had a significant positive effect on employee performance. The partial analysis test results showed that punishment has a significant positive effect on employee performance, leadership has a significant positive effect on employee performance and rewards have no significant negative effect on employee performance.
\end{abstract}

Keywords: leadership, reward, punishment and employee performance

\section{Introduction}

The Central Statistics Agency said that the Indonesian economy in quarter II-2019 compared to quarter II-2018 (y-on-y) grew 5.05 percent. Growth was supported by almost all business sectors except mining and quarrying which decreased by 0.71 percent. The highest growth was achieved by other services by 10.73 percent followed by company services by 9.94 percent, information and communication by 9.60 percent and health services and social activities by 9.09 percent All that can not be separated from the role of the creative industry, Deputy Research, Education, and Development of the Indonesian Creative Economy Agency AR Boy Berawi even said that of 8.2 million creative industry units, $68 \%$ are engaged in the culinary industry.

One of the economic growth in Indonesia is contributed by the food and beverage sector. The Ministry of Industry (Kemenperin) noted the food and beverage sector had an investment value in 2018 valued at $\mathrm{Rp} 56.20$ trillion or managed to contribute a national gross domestic product (GDP) of $6.34 \%$. In the 2019 non-oil and gas growth projection, the food and beverage industry sector is projected to grow by $9.86 \%$. The food and beverage sector which contributed to economic growth in Indonesia is the food retail outlets. Food or culinary retail outlets are one of the locomotive drivers of other sub-sectors in the creative industry. This step is expected to be able to encourage people's income directly and be able to increase economic growth ${ }^{[22]}$. 
Sambel Layah Corp is one of the culinary retailers that has many outlets spread across almost all of Central Java Province, Yogyakarta Special Region (DIY) and West Java. Sambel Layah Corp currently has 14 brands with their uniqueness that are able to attract the interest of consumers. From this business development, of course Sambel Layah Corp has been able to maintain the quality of service and product quality so that it can compete (SL Corp Purwokerto). Sambel Layah Corp has the tagline "Powerful and Phenomenal" is able to provide services for all people from adolescents to adults. One of the modern outlet concepts provided by Sambel Layah Corp is \#WKWK Food and Drink which is able to attract teenagers through unique, modern and millennial design concepts so that they are able to compete with similar business actors and can maintain their existence. For other brands owned by Sambel Layah Corp, they also have a variety of unique concepts, of course by presenting various product innovations (SL Corp Purwokerto).

The organization must be able to create situations and conditions that recognize and enable employees to develop abilities and skills optimally, especially in terms of performance ${ }^{[5]}$. Employees as human resources are the most important factors among other factors of production in the organization because human resources plan, implement, and control every activity of the organization to achieve goals. Workers or employees cannot and should not be equated with factory equipment or machines because workers are people who have diverse personalities that can affect employee performance. The fact is often found that in conditions of work requirements have been met, employee performance is still felt to be too ${ }^{[6]}$.

Leadership is the ability that a person has to influence others to work towards their goals and objectives ${ }^{[10]}$. Previous research obtained the results of hypothesis testing proving that leadership has a positive and significant effect on employee performance ${ }^{[20]}$. Employee performance can also be influenced by reward and punishment. Rewards are something given by the company to employees on the basis of sacrifice of time, energy, and mind ${ }^{[29]}$. Previous research obtained the results of hypothesis testing proving that reward has a positive and significant effect on employee performance ${ }^{[28]}$.

Punishment is defined as the act of presenting unpleasant or undesirable consequences as a result of certain behavior ${ }^{[12]}$. Previous research proved that punishment has a positive and significant effect on employee performance ${ }^{[28]}$. While other research stated that punishment does not significantly influence employee performance ${ }^{[25]}$.

This research is a development research from previous research about the effect of reward and punishment on performance (Study of PT Telkom Indonesia Witel East Java Malang Employees) ${ }^{[28]}$. Researchers added the independent variable of leadership, in this study the leadership in question is leadership in the SL Corp Purwokerto outlet itself. This is because the previous research conducted only examined the effect of reward and punishment without considering other variables such as leadership ${ }^{[28]}$. This research is expected to provide input to Sambel Layah Corp Purwokerto about employee performance because based on the results of interviews with Mr. Margiono as HRD SL Corp Purwokerto, stated that one of the variables, namely rewards at Purwokerto Corp SL decreased from year to year, 2017 there were 26 people, 2018 there were 19 people, 2019 there were 13 people, because the reward was given using qualifications set by the SL Corp Purwokerto company.

The difference between this research and previous research is that it lies in the location and object of the study. The target of this research is focused on the employees of Sambel Layah Corp Purwokerto. Based on the description that is stated in the introduction and research objectives, the proposed hypotheses are: 


\section{H1: Leadership, Reward and Punishment simultaneously affect employee performance \\ H2: Leadership has positive effect on employee performance \\ H3: Reward has positive effect on employee performance \\ H4: Punishment has positive effect on employee performance}

\section{Literatur Review}

\subsection{Employee Performance}

Abdullah (2014) Employee Performance is a work achievement that is the result of the implementation of a work plan made by an institution implemented by the leadership and employees (HR) who work at the institution both government and company (business) to achieve organizational goals ${ }^{[1]}$. Performance is defined as the results of work in quality and quantity achieved by an employee in carrying out their duties in accordance with the responsibilities given to him ${ }^{[14]}$. The notion of performance is a result of one's achievement in carrying out tasks based on skill and experience, as well as time ${ }^{[3]}$.

\subsection{Leadership}

Leadership is the ability that a person has to influence others to work towards their goals and objectives ${ }^{[10]}$. Management includes leadership, but also includes other functions such as planning, organizing, and monitoring. Leadership is a process of someone's activity to move others by leading, guiding, influencing others, to do something in order to achieve the expected results ${ }^{[29]}$.

\subsection{Reward}

Rewards are something of service provided by companies to employees on the basis of sacrifice of time, energy, and mind ${ }^{[29]}$. Reward is a form of appreciation for a given achievement, either from an individual or an institution that is usually given in material or verbal form.

\subsection{Punishment}

Punishment is a threat of punishment aimed at maintaining applicable regulations and giving lessons to violators ${ }^{[14]}$. Punishment is one form of negative reinforcement that becomes a motivational tool if given appropriately and wisely with the principles of punishment ${ }^{[4]}$.

\section{Method}

This study used quantitive approuch. The data used in this study are primary data. Survey method is used in this study using self-report questionnaire which is personally administered to employees at SL Corp Purwokerto. Data analysis was performed by multiple linear regression analysis. Before testing the hypothesis, the descriptive test, the validity test, the reliability test, the classic assumption test used are the normality test, the multicollinearity test, and the heteroscedasticity test, the regression model match test. 


\subsection{Employee Performance}

Employee Performance is a work achievement that is the result of the implementation of a work plan made by an institution implemented by the leadership and employees (HR) who work at the institution both government and company (business) to achieve organizational goals $^{[1]}$. Performance is a function of motivation and ability to complete task or work ${ }^{[6]}$. Employee performance indicators, namely (1) Quality of work; (2) Work quantity; (3) Whether it is reliable or not; (4) Attitude ${ }^{[14]}$.

\subsection{Leadership}

Leadership is a process of one's activities to move others by leading, guiding, influencing others, to do something in order to achieve the expected results ${ }^{[29]}$. Leadership indicators according consists of the source of leadership power, the efforts carried out by French and Paven appear to be widely accepted business results, they divide up on seven sources of indicators namely: (1 ) Position as supervisor; (2) Need for achievement; (3) Intelligence; (4) Decisiveness; (5) Self confidence; (6) Initiatives; (7) Relationships with subordinates ${ }^{[3]}$.

\subsection{Reward}

Reward is a form of appreciation for a given achievement, either from an individual or an institution that is usually given in material or verbal form. Rewards are classified into two categories namely extrinsic rewards and intrinsic rewards ${ }^{[12]}$

\subsection{Punishment}

Punishment can be described as follows: (1) Light punishment; (2) Medium punishment; (3) Severe punishment ${ }^{[28]}$. Punishment is divided into two parts, namely: (1) Punishment (sanctions / punishment) preventive is an action taken by the company to prevent employees from committing violations, including : rules, recommendations and orders, prohibitions, coercion, and discipline. ; (2) Repressive punishments (sanctions / penalties) are actions given by companies to employees who commit violations, including: reprimands, termination of benefits, termination of bonuses, restrictions on the use of company facilities, and termination of employment ${ }^{[4]}$.

\section{Result And Discussion}

\section{a. Validity and Reliability Test}

Significant test is done by comparing the value of $r$ value with $r$ table for degree of freedom $(d f)=(n-2)$, in this case $n$ is the number of samples and with a significant level of $\alpha$ 0.05 in one-way test and obtained a number of 0.1490 . Of the four variables studied, all were declared valid, because the calculated $r$ value of the four variables was greater than the $r$ table (0.1490). In the reliability test of Cronbach's Alpha value of the four variables $>0.70$, the value stated that a questionnaire is said to be reliable or reliable if one's answer to the statement is consistent or stable over time and can be said to be reliable because the Cronbach's Alpha value on all variables $>0.70^{[8]}$. 


\section{b. Classic assumption test}

\subsubsection{Normality}

Kolmogorov-Smirnov test SPSS output results obtained Asymp values. Sig (2-tailed) of $0.75>0.05$, it can be concluded that the residual data are normally distributed.

\subsubsection{Multicollinearity}

The SPSS test results obtained that the variable has a value of Tolerance $>0.10$. The leadership variable has a Tolerance value of $0.509>0.10$, the reward variable has a Tolerance value of $0.264>0.10$, and the Punishment variable has a Tolerance value of $0.339>0.10$. Also with the VIF value each variable has a value of $\leqslant 10$. The leadership variable has a VIF value of $1.964 \leqslant 0.10$, the Reward variable has a VIF value of $3.787 \leqslant 0.10$, and the Punishment variable has a VIF value of $2.951 \leqslant 0.10$. From these data, this research data is free from multicollinearity assumptions.

\subsubsection{Heteroscedasticity}

In testing heteroscedasticity it is known that the significance value of the leadership variable is $0.894 \geqslant 0.05$ reward variable is $0.211 \geqslant 0.05$ and the punishment variable is $0.987 \geqslant 0.05$, it can be interpreted that the regression model is free from heterocedasticity because the significant value is $>0.5$.

\subsection{Multiple linear regression analysis}

Multiple regression analysis is used to analyze the effect of several independent variables on the dependent variable together. In this study, the independent variables are Leadership (X1), Reward (X2), Punishment (X3) while the dependent variable is Employee Performance (Y). The results of multiple linear regression analysis can be seen in table 1 as follows:

Table 1. Results of multiple linear regression analysis

\begin{tabular}{|c|c|c|c|c|c|c|}
\hline & & & Coefficients $^{\mathrm{a}}$ & & & \\
\hline & & Unst: & dardized & Standardized & $\mathrm{t}$ & Sig. \\
\hline & & $\mathrm{B}$ & Std. Error & Beta & & \\
\hline & (Constant) & 14.695 & 1.559 & & 9.423 & .000 \\
\hline 1 & Leadership & .029 & .059 & .058 & .500 & .618 \\
\hline & Reward & -.016 & .038 & -.069 & -.422 & .673 \\
\hline & Punishment & .153 & .051 & .431 & 3.003 & .003 \\
\hline
\end{tabular}

The results of the multiple regression analysis test produce the following equation: $\mathrm{Y}=14.695+0.029 \mathrm{X} 1-0.016 \mathrm{X} 2+0.153 \mathrm{X} 3$ Information :

$\alpha=$ constant value $(\alpha)$ shows a positive value of 14.695 stating that if leadership, reward, punishment does not change the employee's performance is 14.695 units.

$\beta 1=$ Value of the regression coefficient Leadership variables indicate the value a positive of 0.029 indicates that each increase in Leadership by 1 unit 
causes Employee Performance to increase by 0.029 units assuming other variables are fixed.

$\beta 2=$ Regression coefficient value Reward variable shows a negative value of 0.016 that every decrease in Reward by 1 unit causes Employee Performance to decrease by -0.016 units assuming the other variables are fixed.

$\beta 3=$ Regression coefficient value Punishment variable shows a positive value of 0.153 that each increase in Punishment by 1 unit causes Employee Performance to increase by 0.153 units assuming other variables are fixed.

\subsection{Test of determination}

Adjust R2 value of the regression model formed in this study amounted to 0.149 it means that the ability of the independent variable leadership, reward and punishment in explaining the dependent variable of employee performance is $14.9 \%$ and the remaining $75.1 \%$ is explained by other variables not included in this research model.

\subsection{Hypothesis Testing}

\subsubsection{F Test (Simultaneous Test)}

The first $\mathrm{F}$ calculated model value is 8,107 with a significance value of 0.000 while the $\mathrm{F}$ table at the 0.05 confidence level is 3.07 . Thus the F count $>\mathrm{F}$ table $(8.107>3.07)$. These results conclude that the first hypothesis test which states that simultaneously the variables of leadership, Reward and Punishment have a significant positive effect on Employee Performance was accepted.

\subsubsection{Partial Test}

Based on the significance of $0.05(\mathrm{df}=\mathrm{n}-\mathrm{k}-1=119)$ then the $\mathrm{t}$ table is 1.65776 because sig $0.618>0.05$ and $t$ value $0.500<1.65776$. Then it can be concluded that leadership has no significant positive effect on employee performance, and the second hypothesis which states that leadership can affect employee performance is not supported. The results of the second hypothesis testing have proven that the leadership variable does not have a significant positive effect on employee performance, it means that the existing leadership in service lay has not been able to improve employee performance. Employees feel leaders have not been able to help and provide freedom for employees to give opinions. And vice versa the higher the existing leadership style will run well, this will affect the performance of employees who have and the employee's performance will improve. Leadership has a positive and not significant relationship to employee performance. Leadership is a process of someone's activities to move others by leading, guiding, influencing others, to do something in order to achieve the expected results ${ }^{[8]}$.

Based on the significance of $0.05(\mathrm{df}=\mathrm{n}-\mathrm{k}-1=119)$ then $\mathrm{t}$ table is 1.65776 . Because sig $0.673>0.05$ and $t$ value $-0.422<1.65776$, it can be concluded that reward has a negative and not significant effect on employee performance, so the third hypothesis state that reward has an effect on employee performance is not accepted. The results of this study conclude that the reward system in Sambel Layah has not been able to motivate employees to improve performance, they may work not based on the desire to get a reward but because they feel a different work culture such as religious example. Such as employees are given the opportunity to carry out worship and routine activities held by PT.Sambel Layah to increase religious knowledge that they might not get if they work elsewhere. Although the results of the study 
show that rewards do not affect employee performance, it does not mean that SL Corp companies do not pay attention to the element of reward for their employees. It is precisely this task for SL Corp management to be able to provide alternative rewards in other forms such as the Umrah program for employees so that employees feel given appreciation as a form of appreciation for their performance results.

Based on table 1 obtained $t$ value of 3.003 and obtained $t$ table with a significance of 0.05 $(\mathrm{df}=\mathrm{nk}-1=119)$ then $\mathrm{t}$ table of 1.65776 because sig $0.03<0.05$ and $\mathrm{t}$ value $3.003>1.65776$ means punishment has a significant positive effect on employee performance. So the fourth hypothesis which states that punishment affects employee performance, can be accepted. The results of the fourth hypothesis testing have proven that the punishment variable has a significant positive effect on employee performance. Which means that SL Corp employees understand and obey all written and unwritten rules and show that punishment is a punishment that aims to remind employees to maintain rules and give lessons to violators. In SL Corp, there is a company regulation which also states that if a violating employee will get punishment for demotion or mutation in the placement of work positions, including punishment for other violations. The results of this study are supported by Tangkuman, et al ${ }^{[30]}$ Based on the results of the test in multiple linear regression analysis results show that punishment has a very significant effect on employee performance at PT. Pertamina (Persero) Manado and Panekenan, et al ${ }^{[18]}$. Basically, the purpose of punishment is to ensure that employees who violate feel deterrent and will not repeat again. Punishment often has a direct effect on correcting bad employee habits, but also the long-term effects on employee behavior usually outweigh the short-term benefits.

\section{Conclusion}

This research was conducted to determine the effect of leadership, reward and punishment on the performance of SL Corporation employees. The results showed that leadership and reward did not affect employee performance while punishment could affect the performance of SL Corp Purwokerto employees. This research is expected to help companies determine the leaders, especially for the leaders of each work unit in SL Corp Purwokerto. This research is also expected to provide input to companies to be able to evaluate the provision of reward in order to further improve employee performance. This study has limitations because it is only carried out in the SL Corporatioan area in Purwokerto. Did not rule out the possibility of obtaining different results if the object of research is broader such as the scope of SL Corp outside Purwokerto.

\section{References}

[1] Abdullah, Ma'ruf. 2014. Manajemen dan Evaluasi Kinerja Karyawan. Yogyakarta: Aswaja Pressindo.

[2] Amri. 2019. Pengaruh Reward Dan Punishment Terhadap Kinerja Karyawan Pada Ksp Balota Kota Palopo. JURNAL JEMMA, Volume 2 Nomor 2 ISSN 2615-5850.

[3] Arianty, Nel. 2015. Pengaruh Kepemimpinan Terhadap Kinerja Karyawan. Jurnal Manajemen Tools. Vol.5 No.1 ISSN 2088-3145.

[4] Astuti, Winda Sri dkk. 2018. Pengaruh Reward dan Punishment Terhadap kinerja karyawan.

[5] Bagis F, BC Pratama, AY Kharismansyah. 2019. Pengaruh Disiplin Kerja, Komitmen Organisasi dan Kepuasan Kerja Terhadap Kinerja Karyawan Studi Kasus Institusi Pendidikan. Jurnal Managemen 13(2). 
[6] Bagis F, BC Pratama, A Darmawan. 2020. Effect of Comprensation on Employee Performance Through Spirit of Work as a Variable of Mediatuon, Case Study in Employees of Islamic Education Institution. Jurnal Ilmiah Ekonomi Islam 6 (2), 259-262.

[7] Fontera Dukung Mitra Usaha Jaga Cita Rasa Melalui Bahan Baku. (https://www.republika.co.id) (Accessed 22 September 2019).

[8] Ghozali, Imam. 2016. Aplikasi Analisis Multivariete Dengan Program IBM SPSS 23. Semarang. Badan Penerbit Universitas Diponegoro.

[9] Gurihnya Industri Kuliner Bikin Ekonomi Nasional Menggeliat. (https://economy.okezone.com). (Accessed 22 September 2019).

[10] Handoko, T. Hani 2011. Manajemen. Jogjakarta: Liberty, Edisi kedua.

[11] Industri Kuliner, Penopang Tertinggi Perekonomian Kreatif di Indonesia. (https://travel.kompas.com). (Accessed 22 September 2019).

[12] Ivancevich, J. M., Gibson, J. L., Donnelly, J. H., \& Konopaske R (2012). Organizations: Behavior, Structure, Processess. New York: The McGraw-Hill, Inc.

[13] Mahmudi. 2015. Manajemen Kinerja Sektor Publik. Yogyakarta: Penerbit UPP STIM YKPM. Edisi Ketiga.

[14] Mangkunegara, Anwar Prabu. 2015. Manajemen Sumber Daya Manusia Perusahaan. Bandung: PT Remaja Rosdakarya.

[15] Muhammad Ali K dkk. 2019. Pengaruh Rekrutmen, Seleksi, Reward dan Punishment Terhadap Kinerja Karyawan Pada Kantor PDAM Kab.Majene. Jurnal Ilmu Ekonomi, Volume 2. No. 4

[16] Muizu, Wa Ode Zuznita dkk. 2019. Pengaruh Kepemimpinan terhadap Kinerja Karyawan.Jurnal Perwira | Volume 2, Nomer 1 E-ISSN: 2655-5638.

[17] Nugroho, Agung Dwi. 2015. Pengaruh Reward Dan Punishment Terhadap Kinerja Karyawan Pt Business Training And Empowering Management Surabaya. Jurnal MAKSIPRENEUR, Vol. IV, No. 2.

[18] Panekenan, Ragitha M dkk. 2019. The Influence Of Reward And Punishment Toward Employee's Performance At Bank Indonesia Branch Manado. Jurnal EMBA. Vol.7 No.1 ISSN 2303-1174.

[19] Pertumbuhan Ekonomi Indonesia Triwulan II-2019 No. 65/08/Th.XXII. (https://www.bps.go.id). (Accessed 22 September 2019).

[20] Priyamedha, A.A. Hastya dan Wayan Gede Supartha. 2019. Pengaruh Diklat, Kepemimpinan dan Hubungan Industrial Terhadap Kinerja Karyawan. E-Jurnal Manajemen, Vol. 8, No. 7, 2019 :4619-4646 ISSN : 2302-8912.

[21] Ramya Inggita, Manikottama dkk. 2019. Pengaruh Motivasi, Lingkungan Kerja Dan Kepemimpinan Terhadap Kinerja Karyawan Pt Satu Visi Edukasi. Jurnal Aplikasi Manajemen dan Bisnis, Vol. 5 No. 2 , ISSN: 2528-5149.

[22] Sari, Novita. 2018. Pengembangan Ekonomi Kreatif Bidang Kuliner Khas Daerah Jambi. Jurnal Sains Sosio Humaniora. Volume 2 Nomor 1.

[23] Sektor Kuliner Kuliner Indonesia Tumbuh 12,7\%. https://ekbis.sindonews.com/ (Accessed 16 November 2019).

[24] Slamet Ahmadi dan Sulistyono. 2018. Pengaruh Kompetensi, Kepemimpinan, dan Disiplin Kerja Terhadap Kinerja Pegawai Di Kantor Pertanahan Kabupaten Bogor. Jurnal Manajemen Kewirausahaan Vol. 15 No. 02 e-ISSN 2654-9247.

[25] Suak, Raymond dkk. 2017. Pengaruh Reward Dan Punishment Terhadap Kinerja Karyawan Sutanraja Hotel Amurang. Jurnal EMBA Vol.5 No.2 ISSN 2303-1174

[26] Sugiyono. 2015. Metode Penelitian Kuantitatif, Kualitatif dan R\&D. Bandung: Alfabeta

[27] Suprapta, Made dkk. 2015. Pengaruh Kepemimpinan Terhadap Kepuasan Kerja dan Kinerja Karyawan (Studi Pada Wake Bali Art Market Kuta-Bali). E-Jurnal Ekonomi dan Bisnis Universitas Udayana 4.06 ISSN : 2337-3067

[28] Suryadilaga, Rendra Maulana dkk. 2016. Pengaruh Reward Dan Punishment Terhadap Kinerja (Studi Pada Karyawan Pt Telkom Indonesia Witel Jatim Selatan Malang). Jurnal Administrasi Bisnis (JAB). Vol. 39 No.1.

[29] Sutrisno, Edy. 2019. Manajemen Sumber Daya Manusia. Jakarta: Penerbit Prenadamedia Group. 
[30] Tangkuman, Kevin dkk. 2015. Penilaian Kinerja, Reward, Dan Punishment Terhadap Kinerja Karyawan Pada Pt. Pertamina (Persero) Cabang Pemasaran Suluttenggo. Jurnal EMBA. Vol.3 No.2 Juni 2015 ISSN 2303-1174.

[31] Wahyuni, dkk. 2018. Pengaruh Pemberian Penghargaan (Reward) Dan Sanksi/Hukuman (Punishment) Terhadap Kinerja Pegawai Di Kantor Kecamatan Tanjung Redeb Kabupaten Berau. eJournal Administrasi Negara, Volume 6, Nomor 4 ISSN 2541-674x.

[32] Widodo, Djoko Setyo. 2017. The Effect of Compensation, Leadership and Organizational Culture Through Work Motivation On Employee Performance Jurnal Manajemen \& Kewirausahaan Vol 5, No.2 